\title{
Effect of starvation and subsequent feeding on glycogen concentration, behavior and mortality in the golden mussel Limnoperna fortunei (Dunker, 1857) (Bivalvia: Mytilidae)
}

\author{
Nelmara I.S. CORDEIRO, ${ }^{1,2}$ Jennifer T.M. ANDRADE, ${ }^{1,3}$ Lângia C. MONTRESOR ${ }^{4}$ Dalva M.R. LUZ, ${ }^{1,2}$ \\ Carlos B. MARTINEZ, ${ }^{2}$ Gustavo DARRIGRAN, ${ }^{5}$ Jairo PINHEIRO,${ }^{6}$ Teofânia H.D.A. VIDIGAL ${ }^{1,2^{*}}$
}

\begin{abstract}
${ }^{1}$ Laboratório de Malacologia e Sistemática Molecular, Departamento de Zoologia, Instituto de Ciências Biológicas, Universidade Federal de Minas Gerais, Av. Antônio Carlos 6627, 31.270-901 Belo Horizonte, Brazil; ${ }^{2}$ Laboratório de Estudos de Limnoperna fortunei, Centro de Pesquisas Hidráulicas e Recursos Hídricos, Universidade Federal de Minas Gerais, Av. Antônio Carlos 6627, 31.270-901 Belo Horizonte, Brazil; ${ }^{2}$ Programa de Pós-Graduação em Zoologia, Departamento de Zoologia, Universidade Federal de Minas Gerais, Av. Antônio Carlos 6627, 31.270-901 Belo Horizonte, Brazil; ${ }^{4}$ Laboratório de Malacologia, Instituto Oswaldo Cruz, Fundação Oswaldo Cruz, Av. Brasil 4365, Manguinhos, 21.040-900 Rio de Janeiro, Brazil; ${ }^{5}$ Consejo Nacional de Investigaciones Cientificas y TecnicasArgentina, Divisíon Zoología Invertebrados, Facultad Ciencias Naturales y Museo, Paseo del Bosque, 1900 La Plata, Argentina; ${ }^{6}$ Departamento de Ciências Fisiológicas, Instituto de Biologia, Universidade Federal Rural do Rio de Janeiro, BR465, Km7, 23.897-000 Seropédica, Brazil
\end{abstract}

*Corresponding author: teofania.vidigal@gmail.com

\section{ABSTRACT}

The success of Limnoperna fortunei as an invasive species is related to its physiological plasticity that allows them to endure adverse environmental conditions. Starvation tolerance is considered to be an important trait associated with bivalve invasiveness. In natural ecosystems, food resources can vary during the year, exposing mussels to variable periods of starvation or limited food availability. Thus, mussels have developed physiological strategies to tolerate fluctuations in food availability. Glycogen concentration has been used in different monitoring studies as an indicator of the nutritional condition of bivalves. The aim of this study was to investigate the physiological responses of $\mathrm{L}$. fortunei based on the glycogen concentrations of specimens under four treatments, comprising different combinations of feeding and starvation, during 125 days. The experiment was carried out in two phases. In the phase I, mussels were divided in two treatments: starvation $(S)$ and feeding $(F)$. After 100 days, tissue samples were collected to quantify glycogen concentrations and, each phase I group was divided in two subgroups: starvation $(S)$ and feeding $(F)$, resulting in four treatments. In the phase II, that lasted 25 days, starvation specimens (S) from phase I were allowed to feed (starvation-feeding treatment, or S-F), or continued to undergo starvation (starvation-starvation treatment, or $S$-S) and the feeding specimens $(F)$ continued feeding (feeding-feeding group, or F-F), or were subjected to starvation (feeding-starvation treatment, or F-S). Behavior (valve-closing) and mortality were recorded in 24 h intervals. After the 25 days (phase II) all specimens were killed, and their soft tissue was removed to quantify glycogen concentrations. The glycogen concentration of the S-F treatment was lower than that of the F-S treatment, which was initially allowed to feed (phase I) and then subjected to starvation (phase II). Stability in the glycogen concentrations was observed when the phase II feeding conditions were maintained during the experiments, as observed in the $S$-S (continued starvation) and F-F (continued feeding) treatments. Based on our glycogen concentrations results, the golden mussel shows a higher tolerance to starvation (125 days) than has previously been published, which suggests that its tolerance strongly influences its invasive behavior.

Key words: Bioinvasion; glycogen; golden mussel; starvation; comparative physiology.

Received: March 2016. Accepted: July 2016.

\section{INTRODUCTION}

Limnoperna fortunei (Dunker, 1857), the golden mussel, was first detected in Argentina at the Río de la Plata estuary (Darrigran and Pastorino, 1995), and it spread upstream of the Prata basin to invade five South American countries (Argentina, Paraguay, Brazil, Uruguay and Bolivia). Its macrofouling capacity makes the golden mussel an aggressive invasive species that has detrimental impacts on aquatic ecosystems, electrical power stations and water treatments plants (Darrigran, 2010; Rolla and Mota, 2010). Additionally, Darrigran and Damborenea (2011) observed that L. fortunei is a very effective ecosystem engineer.

The success of L. fortunei as an invasive species is also related with its behavior and physiological tolerance for a wide range of ecological conditions. It can tolerate a wide range of temperatures and salinity and long periods of exposure to air, and it can survive in water up to 40 meters deep and in freshwater habitats with limited food availability (Oliveira et al. 2010; Darrigran et al., 2011). Oliveira et al. (2010) suggested that freshwater habitats with limited food availability and suspended sediments can impair the filtration rates of the golden mussel and may 
limit its abundance but does not preclude its establishment. In fact, starvation tolerance can be an important trait associated with the invasive ability of macrofouling bivalves such as L. fortunei (Chase and McMahon, 1995; Oliveira et al., 2010). Starvation tolerance in the golden mussel has been observed over 63 days by Silva (2006), and the specimens that were not fed showed no weight loss. Starvation tolerance has also been observed in other invasive bivalves, such as the freshwater zebra mussel Dreissena polymorpha (Pallas, 1771) (Bivalvia: Dreissenidae) and the marine blue mussel Mytilus edulis Linnaeus, 1758 (Bivalvia: Mytilidae) (Chase and McMahon 1995).

Limnoperna fortunei feed on phytoplankton, zooplankton and suspended organic particles by filtering water through their gills (Sylvester et al., 2009). In natural ecosystems, the food resources can vary during the year, exposing mussels to short or long periods of starvation (seasonal variation) or limited food availability (Albentosa et al., 2007). Thus, mussels have developed physiological strategies to survive these fluctuations in food availability (Oxford and Fish, 1979). In general, filter-feeding bivalves reduce their filtration rate, by closing their valves, when exposed to low food concentration, demonstrating that closing and gapping the valves, in this case, is a response to food availability (Riisgård and Larsen, 2015). In addition, valve closure promotes an immediate reduction in oxygen consumption (Famme, 1980), and the mussels save energy during stressful periods of starvation by reducing their valve-gap (Riisgård and Larsen, 2015). Valve movement is one the most important bivalve behaviors and has been monitored in experiments involving chemical (Di Fiori et al., 2012; Montresor et al., 2013) and nutritional stressors, such as limited food availability and starvation, under laboratory conditions (Famme, 1980; Higgins, 1980; Riisgård and Larsen, 2015).

The usual response to nutritive stress (starvation) in bivalves is to decrease metabolic rate to a minimum value (basal metabolism), which is maintained throughout the starvation period (Albentosa et al., 2007). However, the energy needed to maintain vital functions in bivalves during periods of starvation or limited food availability differs according to species, sex and life stage (Albentosa et al., 2007; da Costa et al., 2012). The ability to store energetic substrates, such as glycogen and other carbohydrates, is also a critical trait that confers resistance to several stressors, such as temperature changes and transportation (Widdows and Bayne, 1971; Chen et al., 2001). Da Costa et al. (2012) showed that during starvation experiments with larvae of the bivalve Solen marginatus (Pulteney, 1758) (Veneroida: Solenidae) there is a pointof-no-return that denotes the threshold above which larvae can no longer develop or survive even if food is provided again. In their study, after eight days of starvation, food was provided. However, three days later, all larvae died.
The monitoring of the nutritional condition of mussels has been performed by analyzing glycogen concentration (Chen et al., 2001). According to Patterson et al. (1999), glycogen is the primary energy source stored by bivalves and is a good physiological parameter for assessing the health status of mussels (Patterson et al., 1999; Anacleto et al., 2013). Glycogen concentrations have been used in different monitoring studies, such as those conducted over the entire life cycle of bivalves in the field, during starvation under laboratory conditions, during relocation events, after transport via air and water (Cordeiro, unpublished data), and during and after the application of chemical or physical stressors (Thompson et al., 1978; Hummel et al., 1989; Patterson et al., 1999; Chen et al., 2001; Newton et al., 2001; Almeida et al., 2007; Patrick et al., 2006; Yusufzai et al., 2010; Anacleto et al., 2013). According to Zwaan and Zandee (1972), M. edulis presented seasonally weight variations that were similar to changes in its glycogen concentrations, thus suggesting that the bivalve's weight is correlated with the accumulation and metabolic breakdown of glycogen. Because physiological stresses demand high consumption, the organism's metabolic rate increases and glycogen is quickly degraded and released, providing more energy to maintain vital processes (MelloSilva et al., 2011). Stressful situations, such as acute or chronic experiments, air exposure (Hummel et al., 1989), starvation (Pinheiro, 1996), photoperiod changes, high population densities and parasitism (Pinheiro and Amato, 1994), can directly promote glycogen depletion in mollusks and, thereby, predispose the use of proteins and lipids as alternative sources of energy (Nandurkar and Zambare, 2012). However, the use of these alternative sources of energy (e.g., protein catabolism) increases the production of nitrogenous wastes such as ammonia, which is a toxic substance that mussels normally excrete through their gills into the hemolymph fluid and tissues, that could contribute to the organism's stress and have toxic effects (Thompson et al., 1978; Chen et al., 2001).

Thus, according to Chase and McMahon (1995) and to Oliveira et al. (2010), starvation tolerance is considered an important trait for invasive species and is likely associated with bivalves' invasiveness. Thus, considering the ecological importance of this trait, little attention has been given to starvation tolerance and feeding studies in invasive bivalves, such as L. fortunei, in natural ecosystems and/or under laboratory conditions. Furthermore, it is important to conduct different biological studies to increase our knowledge about the golden mussel and improve macrofouling control strategies (Darrigran, 2010; Mansur et al., 2012; Boltovskoy, 2015). In the present study, to investigate the tolerance of $L$. fortunei to starvation, specimens were subjected to different combinations of feeding and starvation, and several responses were analyzed: i) glycogen concentration in the tissue; ii) behavior (valve- 
closing); and iii) mortality. This study provides insights that improve our knowledge about the starvation and feeding of $L$. fortunei under laboratory conditions. The data presented here may contribute i) to the development of rearing protocols aiming to provide good quality animals for laboratory tests; ii) to better understand mechanisms related to their highly successful invasion strategies; iii) to improve prediction models of this species expansion.

\section{METHODS}

Specimens of $L$. fortunei were manually and carefully collected from a hard substrate, avoiding injury to the animals, at Refúgio Bela Vista of Itaipu's hydroelectric power plant (Paraná River), Foz do Iguaçu City, Paraná state,

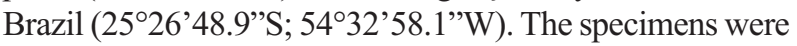
manually and carefully washed using local water (at $25.01 \pm 1.67^{\circ} \mathrm{C}$ ) to remove organic materials. Subsequently, some specimens had their soft tissue removed, stored and maintained at $-20^{\circ} \mathrm{C}$ for later quantification of the glycogen concentration (see details in the Glycogen concentration section) at the laboratory $(0.15 \pm 0.07 \mathrm{mg}$ of glucose / $\mathrm{g}$ of tissue). This procedure was performed to evaluate the glycogen concentrations of $L$. fortunei specimens in their natural conditions and for comparison with specimens maintained under laboratory conditions.

The sampled specimens were packed in plastic bags that included $3 \mathrm{~kg}$ of mussels each without water (air transport). Subsequently, each bag was filled with $\mathrm{O}_{2}$ using an air compressor, closed and kept in a transport box. The thermally insulated boxes ( $24 \mathrm{~L}$ each) were previously cooled and maintained at a low internal temperature (approximately 15 to $17^{\circ} \mathrm{C}$ ) using iced gel during transport. Subsequently, the boxes were transported with the live specimens to the Laboratório de Estudos de Limnoperna fortunei (LELf) at Centro de Pesquisas Hidráulicas e Recursos Hídricos (CPH) of Universidade Federal de Minas Gerais (UFMG), Belo Horizonte city, Minas Gerais state (1952'29.61's; 4358'03.41’W).
Once at the LELf (approximately eight hours of transport), the boxes were opened, the temperatures were individually measured, and 500 grams of mussels were placed in $40 \mathrm{~L}$ aquariums containing dechlorinated tap water (density: approximately 17 individuals $\mathrm{L}^{-1}$ ). Water was dechlorinated with sodium thiosulphate. The temperature difference between the boxes and the water in the aquariums was less than $2{ }^{\circ} \mathrm{C}$ to prevent thermal shock. The experiments were carried out in two phases describe above.

\section{Experiment: phase I}

Mussels were divided into two groups: mussels subjected to starvation (S) and mussels subjected to regular feeding (F) (Fig. 1). Both groups were maintained in their respective aquariums for 100 days with constant aeration and a controlled photoperiod of 12:12 h. No food was provided during the first five days to allow the organisms to acclimate to the laboratory conditions. After this five days period, the group F was daily fed with live algae Scenedesmus sp., Meyen, 1829 (Chlorophyceae: Scenedesmaceae) and Ankistrodesmus, Corda, 1838 (Chlorophyceae: Selenastraceae); $0.5 \times 10^{5}$ cells $\mathrm{mL}^{-1}$ (Owen, 1974; Montresor et al., 2013), which were cultivated in the laboratory. Food was provided three hours before water replacement $(50 \%$ or $100 \%$ daily water replacement). During this period, no food was provided to the treatment $\mathrm{S}$. After 100 days, 25 specimens from each treatment of the phase I (S or F) were killed and their soft tissue was removed to quantify glycogen concentration (see the Glycogen quantification section).

Aquariums were cleaned every two days. Before replacing the water in each aquarium, organic residues and feces were removed using dechlorinated tap water and a thin paint brush. The tap water used in the cleaning procedure was first dechlorinated with sodium thiosulfate and then used in each aquarium to maintain the mussels in the laboratory. To reduce stress on the organisms, none of the specimens were removed from their aquarium, and each

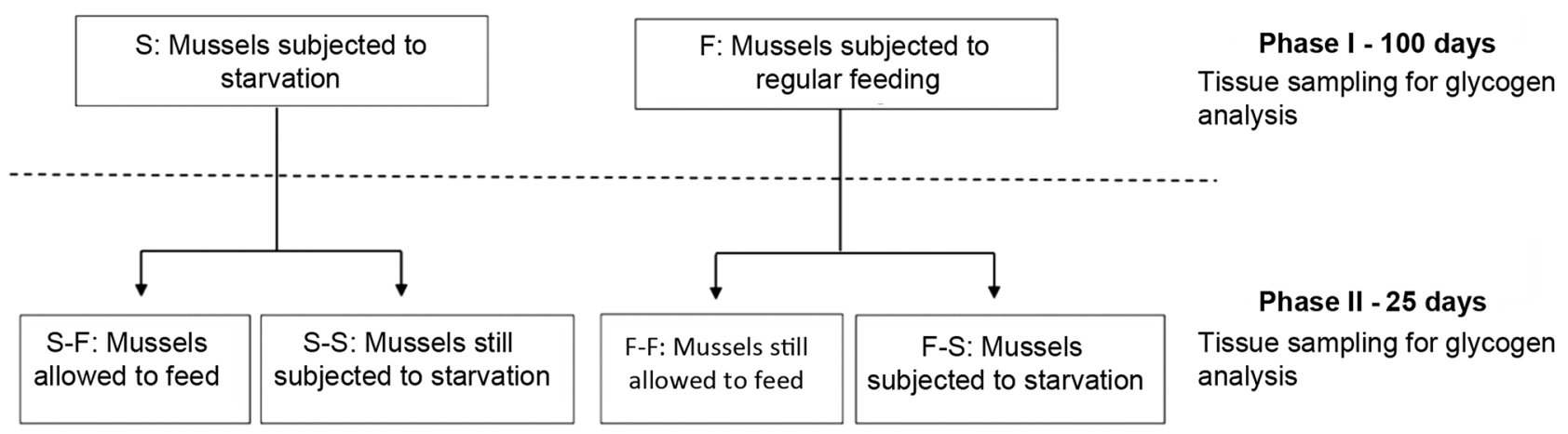

Fig. 1. Schematic representation of the experimental design. 
cleaning procedure was carefully performed to avoid touching them. The physicochemical parameters in the aquariums, including temperature, $\mathrm{pH}$, dissolved oxygen and total ammonia, were monitored daily using a $\mathrm{pH}$ meter (HI 3221, HI 1131B, Hanna Instruments, Woonsocket, RI, USA), an optical oximeter (ProODO, YSI Inc., Yellow Springs, OH, USA), and an ammoniaselective electrode (HI 4101, Hanna), respectively. The aquariums were maintained under the following conditions: $20.03 \pm 2.98^{\circ} \mathrm{C}, \mathrm{pH} 7.7 \pm 0.39,7.63 \pm 0.67 \mathrm{mg} \mathrm{L}^{-1}$ of dissolved oxygen and total ammonia- $\mathrm{N} \leq 0.6 \mathrm{mg} \mathrm{L}^{-1}$.

Two days prior to the phase II of the experiment, 150 mussels (specimens $19.81 \pm 4.38 \mathrm{~mm}$ in shell length) were removed from phase I groups ( $\mathrm{S}$ and $\mathrm{F}$ ) and kept in sterile plastic containers for an acclimation period with dechlorinated water and constant aeration in an incubator at $25 \pm 2^{\circ} \mathrm{C}$ and with a controlled photoperiod of $12: 12 \mathrm{~h}$ light:dark cycle). After 24 hours, specimens that did not attach to the containers and did not present extended siphon were excluded. After $24 \mathrm{~h}$, groups of twenty-five individuals were randomly distributed into 12 plastic containers (4 L each) containing $2 \mathrm{~L}$ of dechlorinated water each under constant aeration. Mussel density in the plastic containers was equivalent to the density in aquariums (approximately 17 individuals $\mathrm{L}^{-1}$ ). The specimens were placed in an incubator and the water was maintained at a $\mathrm{pH}$ of $7.73 \pm 0.11,17.54 \pm 0.38^{\circ} \mathrm{C}, 92.86 \pm 0.68 \%$ oxygen saturation, $8.86 \pm 0.11 \mathrm{mg} \mathrm{L}^{-1}$ of dissolved oxygen and $0.020 \pm 0.02 \mathrm{mg} \mathrm{L}^{-1}$ of ammonia. The plastic containers selected for the phase II were those with all twenty-five specimens attached to the container or to other mussel.

\section{Experiment: phase II}

The mussels selected from each phase I group (100 days at $\mathrm{S}$ or $\mathrm{F}$ ) were subjected to one of two treatments ( 25 days at $\mathrm{S}$ or $\mathrm{F}$ ), resulting in four treatments in the phase II: S-F, S-S, F-F and F-S (Fig. 1). Phase II experiments were carried out in triplicate. The S-F specimens, after 100 days of starvation, began to receive food; the S$\mathrm{S}$ specimens remained under starvation conditions. The F-F group continued to be fed, and the F-S specimens, after 100 days feeding were subjected to starvation. Experiments were carried out using a 2 × 2 factorial design (two previous diets and two new diets throughout the experiment, see the Statistical analysis section for further details) in triplicate ( $\mathrm{n}=75$ per treatment). The mussels subjected to feeding in the phase II (S-F and F-F groups) (Fig. 1) were fed daily three hours before $100 \%$ water replacement. Before the daily water replacement, physicochemical parameters were monitored as described in previous section. During the phase II mortality and valveclosing responses were recorded over 24-h intervals, and dead individuals were removed from the containers twice a day to prevent water quality degradation.
At the end of the phase II (Fig. 1), all specimens, from the four treatments (S-F, S-S, F-F and F-S) were killed and their soft tissue was removed to quantify glycogen concentration (see the Glycogen quantification section).

\section{Glycogen quantification}

The mussels' soft tissues were removed from the shells at the end of each phase. For each group of each phase, three samples of one gram of pooled tissue were collected and stored at $-20^{\circ} \mathrm{C}$. Glycogen concentration from tissues was determined using a spectrophotometer, by 3.5-dinitrosalicylic acid technique (Pinheiro and Gomes, 1994; Sumner 1944) and concentrations were expressed as milligrams of glucose per gram of tissue (mg glucose $g$ tissue ${ }^{-1}$, wet weight).

\section{Statistical analysis}

To check for differences and interactions between the treatments (S and F) received in phase I and II, a factorial analysis of variance (factorial ANOVA) was performed (Zar, 2009). Considering only phase II results, oneway analysis of variance (ANOVA) were performed (Zar, 2009) to test the differences among the treatments S-F, S$\mathrm{S}, \mathrm{F}-\mathrm{F}$ and F-S over the responses i) valve-closing, and ii) mortality. Comparisons were made a posteriori using $95 \%$ confidence intervals, and differences were considered significant for treatments in which there was no overlap in the confidence intervals. All statistical analyses were performed using STATISTICA 8.0 software (StatSoft, 2007).

\section{RESULTS}

\section{Glycogen quantification}

No interaction was found between the diets provided in the phase I and phase II within the tested groups (treatments) (factorial ANOVA: $\mathrm{F}_{3 ; 9}=1.45, \mathrm{P}=0.29$ ). However, a significant difference was found among phase II treatments (diets) (factorial (ANOVA: $\mathrm{F}_{3 ; 13}=4.15, \mathrm{P}=0.04$ ). These differences were observed between the treatments F-S and S-F at the end of the 25-day phase II. Mussel under the treatment F-S $\left(0.44 \pm 0.01 \mathrm{mg}\right.$ glucose $\left.\mathrm{g} \mathrm{tissue}^{-1}\right)$ had a glycogen concentration that was $72.72 \%$ higher than those under S-F treatment $(0.12 \pm 0.05 \mathrm{mg}$ glucose $\mathrm{g}$ tis$\left.\mathrm{sue}^{-1}\right)$. However, those treatments that had the same diet in both phases (S-S and F-F) remained stable when compared to their phase I period and did not show significant differences in their glycogen concentrations from those of the other treatments (Fig. 2 and Tab. 1).

\section{Behavioral response (valve closing) and mortality}

The diet provided in the phase II affected the valveclosing response of $L$. fortunei (ANOVA: $\mathrm{F}_{3 ; 211}=32.40$, 
$\mathrm{P}<0.001)$. Specimens subjected to starvation in the phase I had closed valves throughout almost the entire phase II ( $48.81 \%$ and $49.18 \%$ for S-F and S-S, respectively). In contrast, specimens that were provided food in phase I (F$\mathrm{F}$ and F-S) had a lower occurrence of valve closure in the phase II. Interestingly, the treatments that were fed daily before the phase II showed an opposite behavioral valve response during the phase II. In fact, the mussels from the F-F and F-S treatments had opened valves throughout almost the entire phase II $(22.03 \%$ and $29.55 \%$ with closed valves, respectively, Fig. 3).

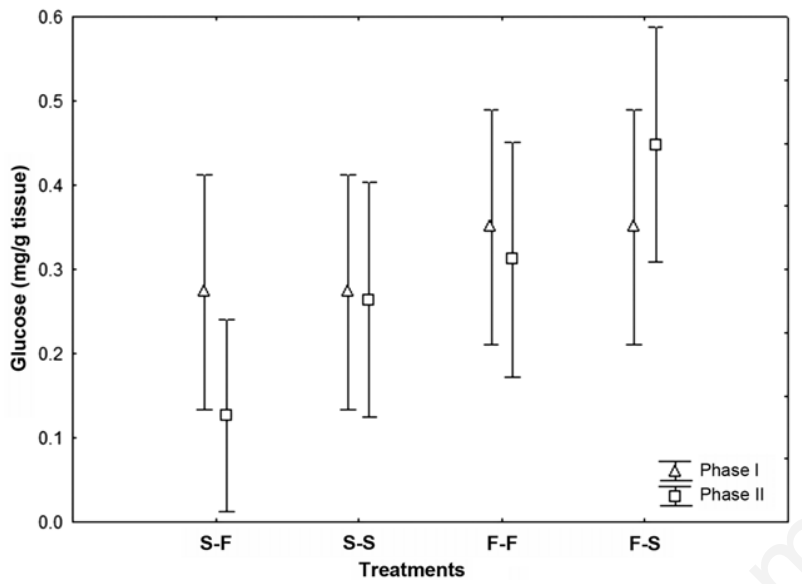

Fig. 2. Average glycogen content (mg glucose/g tissue, wet weight) of Limnoperna fortunei with $95 \%$ confidence intervals for the phase I and phase II.

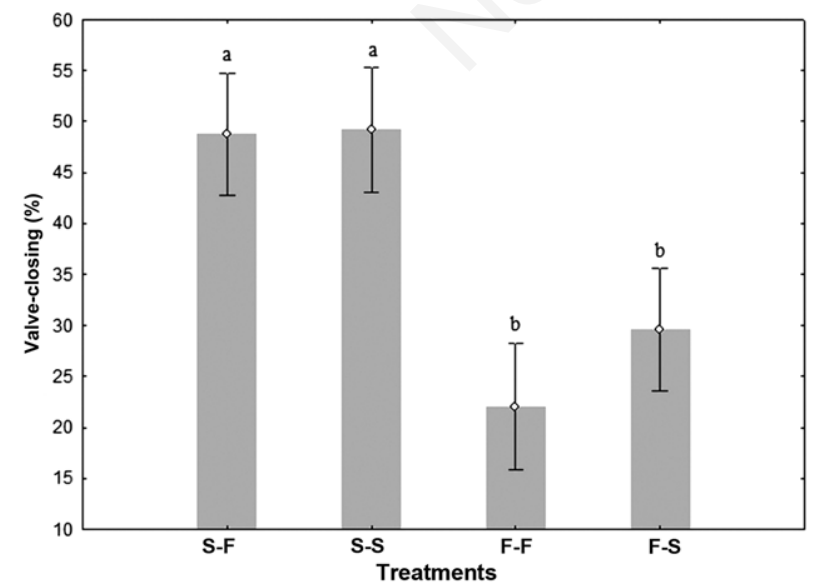

Fig. 3. Valve closing behavior (\%) for the 25 days of the phase II for the different treatments of Limnoperna fortunei with $95 \%$ confidence intervals. The means followed by different letters in the columns are significantly different $(\mathrm{P}<0.05)$.
Significant differences in mortality were observed (ANOVA: $\mathrm{F}_{3 ; 8}=10.72, \mathrm{P}=0.003$ ). The treatments $\mathrm{S}-\mathrm{F}$ and $\mathrm{S}-\mathrm{S}$ showed the highest mortality in the phase II, and this mortality was not dependent on whether the mussels were allowed to start feeding or if starvation was continued (Fig. 4).

\section{DISCUSSION}

Bivalves are considered to be evolutionarily adapted to changes in food abundance and present characteristics (e.g., physiological traits) of animals that inhabit ecosystems in which the scarcity or even total absence of food during variable periods of time is very common (Chase and McMahon, 1995; Albentosa et al., 2007; Riisgård and Larsen, 2015). In fact, bivalves are exposed to an annual cycle of accumulation and use of energy reserves, which is influenced by food availability (Albentosa et al., 2007). Riisgård and Larsen (2015) showed that mussels reduce their oxygen uptake and save energy during starvation pe-

Tab. 1. Mean glycogen concentration values \pm standard deviation (mg glucose/g tissue, wet weight) of Limnoperna fortunei for each treatment group (phase I and phase II).

\begin{tabular}{lcc} 
Treatments & Phase I & Phase II \\
S-F & $0.27 \pm 0.07$ & $0.12 \pm 0.05^{*}$ \\
S-S & $0.27 \pm 0.07$ & $0.26 \pm 0.08$ \\
\hline F-F & $0.35 \pm 0.13$ & $0.31 \pm 0.08$ \\
F-S & $0.35 \pm 0.13$ & $0.44 \pm 0.01^{*}$ \\
\hline
\end{tabular}

$S$, starvation; $F$, feeding; $* P<0.05$.

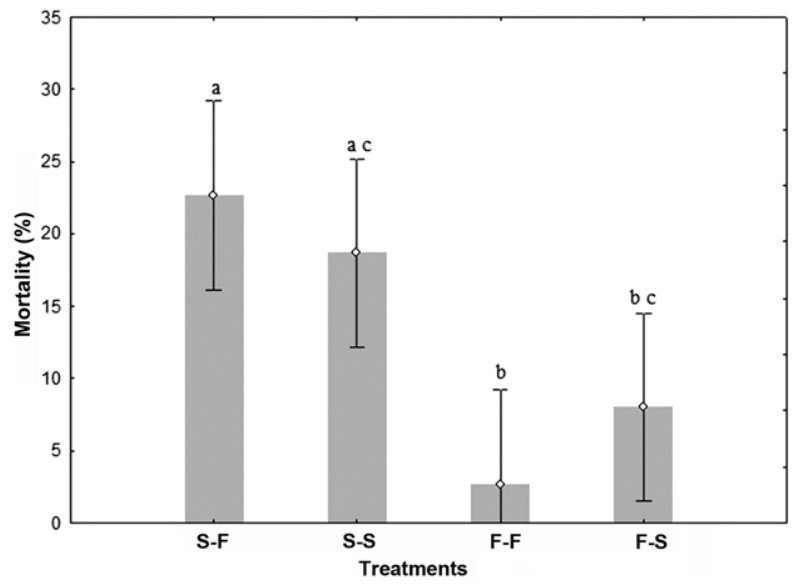

Fig. 4. Total mortality (\%) during the 25 days (phase II) for the different treatments of Limnoperna fortunei with 95\% confidence intervals. The means followed by different letters in the columns are significantly different $(\mathrm{P}<0.05)$. 
riods by closing their valves. Considering each treatment in the phase I and II this study, the feeding regimes tested (feeding or starvation) did not affect the glycogen content of $L$. fortunei specimens. Starvation is considered an extreme nutritive stressor, and the usual physiological response is a decrease in metabolic rate to a minimum value (required to vital functions) throughout the starvation period. Thus, this strategy allows the animal to reduce its energy consumption and save energy during the starvation period - when energy gain is nonexistent or only very minimal (Albentosa et al., 2007). Based on our data, after a starvation period of 100 days (phase I), golden mussels in the S-F treatment, which were provided food during the phase II, most probably used this strategy to maintain its metabolism at a low level, and a reduction of its energy reserve was observed. The glycogen concentration in S-F mussels was lower than in F-S mussels, which were fed during the 100-day phase I and subjected to starvation during the 25-day phase II (Fig. 2).

The ability to survive during periods of food scarcity or even a total absence of food for variable periods of time is related to the physiological condition of the animal before the starvation period. In fact, the most generalized model for this is based on the accumulation of energy during the periods when food is abundant. Thus, using their accumulated energy throughout the starvation period, animals can survive this nutritive stress without a significant impact (Chen et al., 2001). In fact, the absence of significant differences in the glycogen concentrations of the F-S treatment over a short period of time ( 25 days) and the high mortality rate of the mussels in the S-F group over 100 days are in accordance with the ideas mentioned above. Stable glycogen concentrations were observed when the feeding regimes of the phase I remained the same during the phase II, as observed in treatments S-S (continued starvation) and F-F (continued feeding). Thus, our data show that when no changes occur in the mussel's diet between the phase I and II, the glycogen concentrations were stable (i.e., no significant difference was observed). However, it is important to emphasize that glycogen concentrations were maintained in S-S mussels, which were maintained under adverse conditions (starvation stress) for the entire trial. Hummel et al. (1989) mentioned that bivalves undergo a latent period (3 to 7 days in Mytilus edulis), which means that mussels can go through some period of stress during which glycogen is not used. Based on our results, golden mussels showed a higher latency period to nutritive stress (125 days) than M. edulis.

Studies on bivalves have shown that they have a high tolerance to starvation, as long as 63 days for L. fortunei (Silva, 2006), 159 days for M. edulis (Riisgård and Larsen, 2015). The tolerance to starvation can be influenced by the temperature and $D$. polymorpha can survive for 125.9 days when maintained at $25^{\circ} \mathrm{C}$, and for 229 days at $5-15^{\circ} \mathrm{C}$, without mortality (Chase and McMahon, 1995). The differences among the ranges of tolerance to starvation periods of these bivalves may be a consequence of several aspects, such as species-specific resistance traits of these mussels, environmental conditions (e.g., temperature) and the nutritional status of the bivalves prior to the starvation test (Chase and McMahon, 1995; Albentosa et al., 2007; da Costa et al., 2012). However, based on our results of glycogen concentrations, the golden mussel shows a higher tolerance to starvation (125 days) than previously published, and this tolerance could strongly influence its invasive ability. Moreover, an understanding of the starvation tolerance of $L$. fortune $i$ allows us to be more informed about the ecology of this species.

Our data also show that the F-F group, which were fed throughout the phase II, did not present signs of nutritive stress and no significant alterations in glycogen concentration were observed, which suggests that the energetic metabolism of this treatment was not altered during the 125 days of the experiment (phase I and phase II). This information is compatible with the observations of Patterson et al. (1999) that in freshwater bivalves fed throughout the experiment, glycogen concentrations were constant over time. Valve-closing behavior was more frequent in the S-F and S-S treatments, which were subjected to starvation. In bivalves, valve closure is considered an important behavior to save energy to maintain vital functions during stressful periods. In fact, valve-closing is a common behavioral response in bivalves to maintain low rates of oxygen uptake (Famme, 1980; Riisgård and Larsen, 2015). These observations have also been made in the mytilid M. edulis, which is also able to survive for weeks without food by keeping valves closed and controlling glycogen deposits (Riisgård and Larsen, 2015). In fact, in our study, the valve-closing response was smaller in the F-F and F-S treatments, which were fed, than in the S-F and S-S treatments, which were kept under starvation conditions during the phase I. The bivalve filtration mechanism is controlled by changes in food availability. The neuroreceptors in the edge of their mantle are capable of detecting suspended particulates, which promote valve movement during filtration (Higgins, 1980). Thus, the organisms that regularly fed spend more time with open valves and exposed siphon (Higgins, 1980). Riisgård and Larsen (2015) showed that the minimum algal concentration needed to stimulate $M$. edulis to keep its valves open was similar to the algal concentration needed to meet the mussel's maintenance energy demand (e.g., its basal metabolism. Thus, keeping valves open is a behavioral response, which expends energy obtained by feeding, as occurred in the F-F and F-S treatments. When energetic reserves are exhausted, mortality can be observed (Albentosa et al., 2007; da Costa et al., 2012). In fact, our results show that significantly higher mortality rates were ob- 
served in the treatments that were subjected to 100 days of starvation independent of whether they were subsequently fed (S-F and S-S). The animals had a poor survival rate independent were provided food, which is supported by the point-of-no-return proposed by da Costa et al. (2012). Indeed, according to Famme (1980) and Higgins (1980), the initiation of feeding after starvation can increase oxygen consumption and protein catabolism, causing an increase in nitrogenous excretion that could contribute to additional stress (Thompson et al., 1978; Chen et al., 2001) and/or toxic effects in the specimens via ammonia buildup (Montresor et al., 2013).

\section{CONCLUSIONS}

Our data show that $L$. fortunei has an ability to endure periods of starvation with minimal impact on glycogen concentrations and mortality and suggest that this species has a point-of-no-return below 125 days. Our results provide useful information that may contribute to different issues regarding this invasive species. Knowledge on the physiological response to feeding and starvation is useful to the development of better rearing protocols, that will result in good quality animals for laboratory tests, essential to achieve reliable results. The extreme tolerance to starvation showed here reinforces the need for great efforts in order to prevent this species range expansion and indicates its capability to invade water bodies with low concentration of organic matter. This information improves our understanding of the degree of its invasiveness and the process by which it establishes itself in new areas. Incorporating this parameter in prediction models may help to obtain more reliable estimates on the species expansion.

\section{ACKNOWLEDGMENTS}

We thank Dr. A.P. Paglia (UFMG) for statistical support, Dr. D.R. Fernandez (Itaipu Binacional) for logistical support during sampling and especially Dr. S. Ludwig for her valuable help in the correction of this paper. This work was supported by grants from the foundation for research from the State of Minas Gerais (Fapemig) and Vale S.A (CRA - RDP-00097-10); CNPq and Capes.

\section{REFERENCES}

Albentosa M, Fernández-Reiriz MJ, Labarta U, Pérez-Camacho A, 2007. Response of two species of clams, Ruditapes decussatus and Venerupis pullastra, to starvation: physiological and biochemical parameters. Comp. Biochem. Physiol. B. 146:241-249.

Almeida EA, Bainy ACD, Loureiro APM, Martinez GR, Miyamoto S, Onuki J, Barbosa LF, Garcia CCM, Prado FM, Ronsein GE, Sigolo CA, Brochini CB, Martins AMG, Medeiros MHG, Di Mascio P, 2007. Oxidative stress in Perna perna and other bivalves as indicators of environmental stress in the Brazilian marine environment: antioxidants, lipid peroxidation and DNA damage. Comp. Biochem. Physiol. 146:588-600.

Anacleto P, Maulvault AL, Barrento S, Mendes R, Nunes ML, Rosa R, Marques A, 2013. Physiological responses to depuration and transport of native and exotic clams at different temperatures. Aquaculture 408-409: 136-146.

Boltovskoy D, 2015. Limnoperna fortunei: the ecology, distribution and control of a swiftly spreading invasive fouling mussel. Springer Int. Publ., Cham: 476 pp.

Chase R, McMahon RF, 1995. Effects of starvation at different temperatures on dry tissue and dry shell weights in the zebra mussel, Dreissena polymorpha (Pallas). Technical Report EL-95-4. U.S. Army Engineer Waterways Experiment Station, Vicksburg.

Chen LY, Heath AG, Neves R, 2001. An evaluation of air and water transport of freshwater mussels (Bivalvia: Unionidae). Am. Malacol. Bull.16:147-154.

da Costa F, Nóvoa S, Ojea J, Martínez-Patiño D, 2012. Effects of algal diets and starvation on growth, survival and fatty acid composition of Solen marginatus (Bivalvia: Solenidae) larvae. Sci. Mar. 76:527-537.

Darrigran G, 2010. Summary of the distribution and impact of the golden mussel in Argentina and neighboring countries, pp. 389-396. In: G.L. Mackie and Claudi R (eds.), Monitoring and control of macrofouling mollusks in freshwater systems, 2nd ed. CRC Press, Boca Raton.

Darrigran G, Damborenea C, 2011. Ecosystem engineering impacts of Limnoperna fortunei in South America, Zool. Sci. 28:1-7.

Darrigran G, Damborenea C, Drago E, Ezcurra De Drago I, Paira A, 2011. Environmental factors restrict the invasion process of Limnoperna fortune (Mytilidae) in the Neotropical Region: a case study from the Andean tributaries. Ann. Limnol. Int. J. Lim. 47:221-229.

Darrigran G, Pastorino G, 1995. The recent introduction of Asiatic bivalve, Limnoperna fortunei (Mytilidae) into South America. Veliger 38:183-187.

Di Fiori E, Pizarro H, Dos Santos AM, Cataldo D, 2012. Impact of the invasive mussel Limnoperna fortunei on glyphosate concentration in water. Ecotoxicol. Environ. Saf. 81:106-113.

Famme P, 1980. Effect of shell valve closure by the mussel Mytilus edulis on the rate of oxygen consumption in declining oxygen tension. Comp. Biochem. Physiol. A 67A:167-170.

Higgins PJ, 1980. Effects of food availability on the valve movements and feeding behavior of juvenile Crassostrea virginica (Gmelin): Movements and periodic activity. J. Exp. Mar. Biol. Ecol. 45:229-244.

Hummel HL, De Wolf W, Zurberg L, Apon RH, Boggards M, Ruttenberg V, 1989. The Glycogen contents in stressed marine bivalves: the initial absence of decrease. Biochem. Phys. B 94:729-733.

Mansur MC, dos Santos CP, Pereira D, Paz IC, Zurita ML, Rodriguez MT, Nehrke MV, Bergonci PEA, 2012. [Moluscos límnicos invasores no Brasil: biologia, preservação e controle].[Book in Portuguese]. Redes Editora, Porto Alegre: $412 \mathrm{pp}$.

Mello-Silva CC, Vasconcellos MC, Bezerra JC, Rodrigues MD, Pinheiro J, 2011. The influence of exposure to Euphorbia splendens var. hislopii latex on the concentrations of total proteins and nitrogen products in Biomphalaria glabrata in- 
fected with Schistosoma mansoni. Acta Trop. 117:101-104. Montresor LC, Miranda-Filho KC, Paglia A, Luz DMR, Araújo JM, Silva MJS, Gerhard L, Martinez CBE, Vidigal THDA, 2013. Short-term toxicity of ammonia, sodium Hydroxide and a commercial biocide to golden mussel Limnoperna fortune (Dunker, 1857). Ecotoxicol. Environ. Saf. 92: 150-154.

Nandurkar HP, Zambare SP, 2012. Study of acute and chronic treatment of tetracyclineon total lipid contents in various tissues of freshwater mussels, Lamellidens corrianus (Lea) \& Parreysia cylindrica (Annandale \& Prashad). Asian J. Biol. Life Sci. 1:41-44.

Newton TJ, Monroe EM, Kenyon R, Gutreuter S, Welke KI, Thiel PA, 2001. Evaluation of relocation of unionid mussels into artificial ponds. J. N. Am. Benthol. Soc. 20: 468-485.

Oliveira MD, Hamilton SK, Jacobi CM, 2010. Forecasting the expansion of the invasive golden mussel Limnoperna fortunei in Brazilian and North American rivers based on its occurrence in the Paraguay River and Pantanal wetland of Brazil. Aquat. Invasions 5:59-73.

Owen G, 1974. Feeding and digestion in the Bivalvia. Adv. Comp. Physiol. Biochem. 5:1-35.

Oxford GS, Fish LJ, 1979. Ultrastructural localization of esterase and acid phosphatase in digestive gland cells of fed and starved Cepaea nemoralis (L.) (Mollusca, Helicidae). Protoplasma 101:181-196.

Patterson MA, Parker BC, Neves RJ, 1999. Glycogen concentration in the mantle tissue of freshwater mussels (Bivalvia: Unionidae) during starvation and controlled feeding. Am. Malacol. Bull. 15:47-50.

Patrick S, Faury N, Goulletquer P, 2006. Seasonal changes in carbohydrate metabolism and its relationship with summer mortality of Pacific oyster Crassostrea gigas (Thunberg) in Marennes-Oleron bay (France). Aquaculture 252:328-338.

Pinheiro J, 1996. Influence of starvation on the glycogen and galactogen contents in the snail Bradybaena Similaris (Férussac, 1821) (Mollusca, Gastropoda). Arq. Biol. Tecnol. 39:349-357.

Pinheiro J, Amato SB, 1994. Eurytrema Coelomaticum (Digenea, Dicrocoelidae): the effect of infection on carbohydrate content of its intermediate snail host, Bradybaena
Similaris (Férussac, 1821) (Mollusca, Gastrpopda). Mem. Inst. Oswaldo Cruz. 89:407-410.

Pinheiro J, Gomes EM, 1994. A method for glycogen determination in molluscs. Arq. Biol. Technol. 37:569-576.

Riisgård HU, Larsen PS, 2015. Physiologically regulated valveclosure makes mussels long-term starvation survivors: test of hypothesis. J. Mollus. Stud. 81:303-307.

Rolla ME, Mota HR, 2010. Response of a major Brazilian utility to the golden mussel invasion, pp. 396-403. In: G.L. Mackie and Claudi R (eds.), Monitoring and control of macrofouling mollusks in freshwater systems, $2^{\text {nd }}$ ed. CRC Press, Boca Raton.

Silva DP, 2006. [Aspectos bioecológicos do mexilhão dourado Limnoperna fortunei (Bivalvia, Mytilidae)].[PhD Thesis in Portuguese]. Universidade Federal do Paraná.

StatSoft, Inc. 2007. STATISTICA data analysis software system, ver. 8.0.

Sumner JB, 1944. A method for the colorimetric determination of phosphorus. Science 100:413-414.

Sylvester F, Boltovskoy D, Cataldo C, 2009. [Taxas de clareamento: ritmos e impacto], pp. 127-139. In: G. Darrigran and C. Damborenea (eds.), [Introdução a Biologia das Invasões. O Mexilhão Dourado na América do Sul: biologia, dispersão, impacto, prevenção e controle].[Book in Portuguese]. Cubo Editora, São Carlos.

Thompson RJ, Bayne CJ, Moore MN, Carefoot TH, 1978. Haemolymph volume, changes in the biochemical composition of the blood, and cytological responses of the digestive cells of Mytilus californianus Conrad, induced by nutritional, thermal and exposure stress. J. Comp. Physiol. B 127:287-298.

Widdows J, Bayne BL, 1971. Temperature acclimation of Mytilus edulis with reference to its energy budget. J. Mar Biol. Assoc. UK 51:827-843.

Yusufzai SI, Singh H, Shirdhankar MM, 2010. An evaluation of different methods for transportation of the freshwater mussel Lamellidens corrianus (Lea 1834). Aquacult. Int. 18:679-692.

Zar HJ, 2009. Biostatistical analysis, $5^{\text {th }}$ ed. Prentice-Hall, Upper Saddle River: 960 pp.

Zwaan A, Zandee DI, 1972. Body distribution and seasonal changes in the glycogen content of the common sea mussel Mytilus edulis. Comp. Biochem. Physiol. A 43:53-58. 